\title{
The effects of human activities, climatic conditions and land-use factors on water resources development in huai river basin northeast china
}

\begin{abstract}
The causal research design method is most effective in establishing the cause-andeffect associations especially when carrying out findings concerning specific variations on water resources availability and development in relation to several other River Basin operating factors such as human activities, climatic conditions and Land-use. The paper takes advantage of specific scenarios to reveal the trends of relationships between factors measured. It is feasible to analyze the effect and cause for wide range of processes in relation to trends. There are higher levels of internal validity associated with research design method because of systematic subject selection. Present study examines the effects of climate change factors on the processes and relative needs for water uses in domestic, production and eco-water consumption is central to the allocation and conservation of water resources in systems of ecology and economy in arid Northeast of China. The population growth requires adequate supply of water especially during shortages arising melt-water from ice and glacier, abnormal rainfall, and flood disasters. The Soil and Water Assessment Tool (SWAT) has deployed prominently for modelling the physical distribution of hydrology of Huai River Basin to ascertain the influence of land use and climate changes independently. However, its inadequate data causes equivocal and inconsistency results derived from statistical analysis; seemingly poor control measures in the basin; method's cause-effect nature; and restriction to small and headwater basins. The watershed method revealed the effects of climatic conditions and human activities on water resources. However, it is limited by the constant variation to land use patterns usually smaller in large catchments than in small watersheds. There are two small neighbouring watersheds could have same climatic input but not in the case of larger catchments. To solve those problems researchers and stakeholders must find a long-term solution by identifying the affected areas. This paper presents the overview of water resources problem of the basin for future study, plan, and work.
\end{abstract}

Keywords: Water Resource, Modeling, Development, Availability, River Basin, Climate, Land-use, Industries
Volume 2 Issue 2 - 2018

\author{
Rawshan Othman Ali, ',2 Zhao Chunju,' Zhou \\ Yihon,' Muhammad Imran Azam' \\ 'College of Hydraulic and Environmental Engineering, China \\ Three Gorges University, China \\ ${ }^{2}$ Department of Petroleum, Koya Technical Institute, Erbil \\ Polytechnic University, Iraq
}

Correspondence: Rawshan Othman Ali, College of Hydraulic and Environmental Engineering, China Three Gorges University, China, Email rawshanothman@yahoo.com

Received: January 16, 2018 | Published: March 05, 2018

\section{Introduction}

In 2004, Huai River Basin's total gross domestic product (GDP) was estimated at 1.05 trillion Yuan, which is $148 \%$ higher than 1994 records. It is a preponderantly evolving area in China. The numbers of industries serviced by the Huai River Basin are continuously on the increase including paper industry, production of coal chemical, textiles and food processing. One major industry having unprecedented growth on the basis of basin is the agriculture, which has been used to produce rice, wheat, soya beans, and cotton. The basin spreads its tributaries to four main cities including Luohe, Zhenghou, Zhoukou and Bengbu. Again, there are several infrastructural lands such as sluices, dams and other water project constructions. ${ }^{1,2}$ At the heart of the Huai River Basin is droughts controls system which is made up of over 5000 sluices and 57000 reservoirs. ${ }^{3}$ Obviously, Huai River Basin facing several common issues regarding infrastructure around the world. Apart from using certain tributaries as source of water supply for populace; The basin is highly susceptible to pollution from chemical, metal and organic substances. Agricultural practices cause pollution due to chemical wastes washed-off from fertilized land. Similarly, organic and metal wastes are generated by industries around the basin. In addition, most of the cities surrounding the basin whose huge piles of untreated sewages are dumbed or eventually washed-off into it. ${ }^{4}$ In 2009 , sewage of over 8.6 billion $\mathrm{m}^{3}$ was discharged into the Huai River whose $78 \%$ capacity were short of chemical oxygen demand (COD) and ammonia nitrogen $\left(\mathrm{NH}_{3}-\mathrm{N}\right)$ required combinations in drinking water. ${ }^{5}$ As expected, the uncontrolled pollution in river is serious concerned throughout the world. According to studies conducted by $^{3,6-8}$ an estimated 200 or more severe water pollution happened throughout the Huai river basin channels. ${ }^{6-8}$ There is presence of organic pollution prevailed in Huai River especially in tributaries such as Jialu River ${ }^{9}$ and the Jiangsu. ${ }^{7,10,11}$ Nevertheless, much is not done in terms of the effects of hydrochemistry caused by human actions on the Huai River. In another study, ${ }^{3}$ investigated the Huai River's ion chemistry control mechanisms; but, no mention was made to specific statistics for dry season situation. Consequently, a sampling campaign was embarked upon in middle of 2009 which is dry season in order to identify the hydrochemistry in the upper spreads of Bengbu Sluice in Huai River Basin. 
The processes of hydrology are majorly caused by climate and land use. There is ever increasing rate of human advancements giving rise to intense changes universally both in climatic conditions and forms of land-use in catchments. In general, the effects of these changes on environment and ecological advancement are receiving extensive attention. ${ }^{12-15}$ On a catchment scale, the effects of these processes of hydrology including infiltration, groundwater recharge and runoff continue to adversely take tolls in the sense of balance of water resources' demand and supply and quality of water; thereby causing imbalances in environment, ecosystems, and economy at large. The direct consequences of land use change are rate of flood incidences, ${ }^{16}$ base-flow ${ }^{7}$ and annual mean discharge, ${ }^{17}$ whereas the variability of climate can alter the peak-flows, flow routing time, and volume. ${ }^{18}$ In future, an effective planning, management and water resources development requires an adequate knowledge of the influences of climate variability and land use forms on hydrological processes. In the past, the watershed method was used to analyse the effects of land use changes in hydrologic processes. ${ }^{19}$ This method involves monitoring of pre- and post-land use change; thereafter, statistical tests of hypotheses are deployed in order to determine land use change impacts on the watershed hydrological responses. The paired watershed method is offered certain levels of understanding of the plant-soil atmosphere interaction, though with noticeable shortcomings. ${ }^{20}$ The reasons being that the difference due to land use change is usually smaller in large catchments than in small watersheds; two small neighbouring watersheds might receive a similar climatic input, whereas this becomes more unlikely for larger catchments.

Another method of estimating the effect of management on water, chemical yields of agriculture, and sediment is known as Soil and Water Assessment Tool (SWAT). SWAT is a physically based, basinscale, spatially distributed and continuous-time method operating on basis of a daily time step whose goal is to estimate the influence of management on agricultural chemical yields, sediment and water in watersheds. The operation of SWAT involves dividing a watershed into numerous sub-watersheds and also, the sub-watersheds are divided into hydrologic response units (HRUs), which are composed management, homogeneous land use, and soil characteristics. The HRUs depict fractions of the sub-watershed area and are unrecognized spatially within a SWAT operation. Similarly, a watershed can be broken down into only sub-watersheds using criteria such as soil type, land use, and management. There are a number of works carried with SWAT method on different watersheds varieties and sizes. ${ }^{21-28}$ Investigated the effects of best management practices implementation on pesticide fluxes contaminating surface water by means of SWAT method. Again, ${ }^{29}$ applied SWAT to examine the effects of land cover change on groundwater flow, entire water yields, and quick flow in the Motueka River catchment/section. Later, ${ }^{30}$ studied the SWAT method for the Xixian watershed hydrological modelling and compared outcomes to the XAJ method $a^{31} d^{31}$ evaluated the impact of tile drainage systems on composition of stream flow in in a Tile-Drained lowland section/catchment with application of the SWAT.

\section{Description of the study area}

The study area extends from $30 \_550 \mathrm{~N}$ to $34560 \mathrm{~N}$ and $111550 \mathrm{E}$ to 117 300E, which encompasses the upper reaches of Bengbu Sluice, including the Ying River, Guo River, Shi River, Feng River, Pi River, and the main stream of the Huai River. The Huai River originates from the Tongbai Mountain in Henan Province, flows easterly through southern Henan, northern Hubei, northern Anhui, and northern Jiangsu, finally into the Yangtze River at Jiangdu, Yangzhou. The largest tributary of the study area is Ying River and the second is Guo River. The former originates from the Funiu Mountain in western Henan Province. It has a length of $1,078 \mathrm{~km}$ and a drainage area of $36,728 \mathrm{~km}^{2}$. The latter is $380 \mathrm{~km}$ long, with a contributing area of $15,900 \mathrm{~km}^{2}$. Elevation of the study area ranges from about $23 \mathrm{~m}$ to $2,153 \mathrm{~m}$. Variations in elevation are indicative of different land-use patterns and climatological changes. The west portion of study area is more hilly, while the east part is relatively level. Soils investigated include brown soil, cinnamon soil, yellow brown soil in the mountainous area, and yellow moist soil in the plain. They are developed under natural vegetations of coniferous broadleaved forest in the west and fruit forest, robinia and poplar in the east. Over 50\% of the study area is cultivated land. The chief enterprises are cloth, chemical pesticides in Zhengzhou, food processing, textiles, alcoholic beverages in Zhoukou, and wine, yarn in Bozhou, Fuyang, and Bengbu. The major urban areas are the metropolitan area of Zhoukou, Fuyang on the Ying River, Bozhou on the Guo River, and Bengbu on the Huai River (Anhui Provincial Bureau of Statistics, NBS Survey Office in Anhui 2010; Henan Provincial Bureau of Statistics, Henan Survey Office of NBS 2010). The climate throughout the study area varies from northern semi-tropics to sub-humid with warm, moist summers and cool, dry winters.

The average temperature in study area is about $11.8-16^{\circ} \mathrm{C}$; the temperature often reaches $28^{\circ} \mathrm{C}$ in summer and drops below freezing in winter when occasional cold fronts move through the area. The mean annual precipitation was $600-1,400 \mathrm{~mm}$ per year and most of the precipitation falls in the form of rain during the four-month period from June through September, i.e., the flood season of the river basin. ${ }^{32}$ Monthly variations in the water discharge of the Huai River main channel show an appreciable seasonal variability, with low discharges in dry season (October-May) and high values in wet season (JuneSeptember). The average discharge in July in Bengbu accounts for about $30 \%$ of annual discharge. ${ }^{7}$ Bengbu Sluice, constructed in 1959 and located on the middle reach of the Huai River, is the only dam on the main stream of the river in Bengbu City, Anhui Province. ${ }^{8}$ The mean annual stream flow at the Bengbu station is about 30.5 billion $\mathrm{m}^{3}$. The geology of the study area is relatively complex. The study area is one of the transitional areas between the mountains in the west and the plain in the east. The Pi River flows from granite, gneiss, schist, clasolite, and Quaternary alluvium. The lithology of Feng River is dominated by Quaternary alluvium. The Shi River and Huai River flow from granite, gneiss, schist, clasolite, Quaternary lacustrine-alluvium, and Quaternary alluviumdiluvium. The Ying River originating from the northwestern HRB drains primarily granite, andesite, carbonate, schist, clasolite, and Quaternary lacustrine alluvium and Quaternary alluvium-diluvium. The Guo River flows initially through Quaternary Aeolian, then through lacustrinealluvium and quaternary alluvium.

\section{Growth and development huai river basin's water resource}

Land use/land cover and climate change can significantly alter water cycle at local and regional scales. Xixian Watershed, an important agricultural area in the upper reach of the Huaihe River, has undergone a dramatic change of cultivation style, and consequently substantial land use change, during the past three decades. A marked increase in temperature was also observed. A significant monotonic increasing trend of annual temperature was 
observed, while annual rainfall did not change significantly. There are 42 counties in the HRBSP. Starting from west to east, the cities of Heze, Jining, Zaozhuang, and Linyi consist of 9, 12, 6, and 12 counties respectively. The industrial output values and the discharge of industrial wastewater, $\mathrm{COD}$, and $\mathrm{NH}_{3}-\mathrm{N}$ were documented at the county-wide in 2010 . Three parameters for measuring water quality including $\mathrm{NH}_{3}-\mathrm{N}$, industrial wastewater discharge, and COD were used in the west region of the river basin showed greater discharges when compared to the eastern region, and pollutant discharges in nearby Nansi Lake were at high level than other regions. Obviously, there were regional discrepancies in values of industrial output, COD discharges, $\mathrm{NH}_{3}-\mathrm{N}$, industrial wastewater. The regions having huge industrial wastewater discharges were centrally situated. Regions in east revealed lesser and stable quantities of industrial wastewater discharges as against those in the west. In addition, counties with high rates of $\mathrm{NH}_{3}-\mathrm{N}$ and industrial COD discharges were mostly in the western region. In general, the discharge intensities of industrial pollutant followed industrial output values with particular reference in regions such as Yanzhou, Tengzhou, and Rencheng. Conversely, entire industrial output was considerably greater, while industrial pollutants discharges were lower in the Luozhuang District and
Zoucheng, while the opposite event in certain outside regions. In 2010 , the association between industrial output values and discharges of industrial wastewater was examined using a correlation analysis at the county level that revealed significant correlation values of 0.01. Again, a significant correlation existed between the quantities of industrial wastewater, industrial output value and industrial COD discharges (that is, 0.614 and 0.312 correlation indices respectively) as depicted in Table 1. The construction materials are considered as high-energy-consumption/low-output/high pollution industries; textiles, electric power, and petrochemical are considered as highenergy-consumption/high-output value/high-pollution industries; and the medical manufacturing and mechanical sectors are low-energyconsumption/high-output value/low-pollution industries. The food processing industry contributed $11.4 \%$ of economic production, and $23.55 \%$ and $26.05 \%$ of $\mathrm{COD}$ and $\mathrm{NH}_{3}-\mathrm{N}$ discharges respectively. Also, it was found that no significant correlation existed between the quantity of industrial $\mathrm{NH}_{3}-\mathrm{N}$ discharge and value of industrial output. The GDP per capita of the HRBSP and the four cities situated nearby (that is, Heze, Zaozhuang, Jining and Linyi) is expressed as the economic factor, and the industrial wastewater discharge is expressed as the industrial load factor.

Table I Correlation between pollution load and industrial output in Huai River Basin and Shandong Region (Guoyong, Qiuhong, \& Scott, 2015)

\begin{tabular}{lllll}
\hline & $\begin{array}{l}\text { Industrial output } \\
\text { value }\end{array}$ & Wastewater & Industrial COD & Industrial $\mathbf{N H}_{3}-\mathbf{N}$ \\
\hline Industrial output value & $\mathrm{I}$ & $0.614^{* *}$ & $0.312^{*}$ & 0.233 \\
Wastewater discharge & $0.614^{* *}$ & $\mathrm{I}$ & $0.813^{* *}$ & $0.592^{*}$ \\
Industrial $\mathrm{COD}$ & $0.312^{*}$ & $0.813^{* *}$ & $\mathrm{I}$ & $0.755^{* *}$ \\
Industrial $\mathrm{NH}_{3}-\mathrm{N}$ & 0.233 & $0.592^{* *}$ & $0.755^{* *}$ & $\mathrm{I}$ \\
\hline
\end{tabular}

*Correlation is significant at the 0.05 level; **Correlation is significant at the 0.01 level

According to ${ }^{33}$ GDP per capita in the HRBSP revealed speedy progression between 2001 and 2010 because the regression curve grew steadily but flattened later, particularly during periods exceeding 2008. The Zaozhuang and Jining cities experienced innovative economic growth that generated greater industrial wastewater discharges as against Heze and Linyi cities. The regression curves for the Zaozhuang and Linyi cities compressed. The regression curve fluctuation for Jining city decreased, which showed signs of a rebound after 2004 and but gradually improved, whereas the regression curve for the Heze city rose abruptly. The GDP of the four prefecture-level cities improved suddenly at $18.2 \%$ per annum, which indicates the speediness of economic growth, particularly in the Heze city that has the fragile economic grounds in Province of Shandong. At the beginning stages of economic growth, industrial water pollution treatment investment could be negligible. During early stages of industrialization, the primary industries were trailed by secondary industries. Results of industrialization led to a greater percentage of secondary industries as against primary and tertiary industries. The decline of primary industries by less than $20 \%$ was matched with the corresponding secondary industries though surpasses tertiary industries, which was known as mid-stage of industrialization process. Whereas primary industries drop to nearly $10 \%$ which led to the amount of secondary industries reaching its highest; at advanced stage of industrialization, the amount of secondary industries turn out to be comparatively steady or slightly dropped. The supremacy of tertiary over secondary industries gave rise to the emergence of the post-industrial phase. ${ }^{33,34}$ In 2010, it was estimated that the GDP of the HRBSP was put at 810.14 billion Yuan. The primary, secondary, and tertiary sectors contributed $11.32 \%, 50.23 \%$, and $38.46 \%$ of the industrial arrangement in the study area, with respect to industrial outputs valued at $100.71,430.77$, and 278.66 billion Yuan. The magnitudes of the three sectors within the study area were 9.2: 54.2: 36.6. The environmental quality is a primary factor on structure of industry. When industrialization is mid-stage, heavy industries have larger influence on the environment when put-side-to-side with agriculture, because of greater utilization of natural resources and speedy increases in waste creation. In fact, this leads to quick deterioration on quality of environment. In 2010, the water quality was Grade IV at 10 monitoring sites (1-3, 5-8, 11, 12, and 14), Grade $\mathrm{V}$ at Xiangzimiao, and lower than Grade $\mathrm{V}$ at two monitoring stations (Dongshifo and Xishifo). The water quality at these stations was short of regulatory standards on water quality goals. The water quality at state-run monitoring stations improved gradually between 2006 and 2010. Even if, it has been impossible to attain the requirements for water quality at these stations, local governments have delivered guidelines and made rigorous efforts to enhancing conditions of water quality.

\section{Huia river basin water resource management efforts}

There are several efforts to manage water resource in Huai River 
Basin as follows:

\section{a. Water vapour sources and changing laws of the climate}

Terrain is considered a great influence on the water vapour transfers. Water vapour is the material foundation of precipitation. Again, there is a significant correlation between precipitation and exterior water vapour transfer and convergence. Therefore, efforts can be focused on understanding the changing laws and climate mechanisms and hydrological factors under the weak water vapour convergence situations of the arid northwest region in order to analyse water vapour transfer and sources. In the works of, ${ }^{35,36}$ it was found that polar ice ocean systems and westerly weather systems are the foremost sources of water vapour transfer to northern and southern Xinjiang in northwest region of China. More so, the Hexi Corridor in the eastern region of Northwest China is greatly inclined to subtropical weather systems such as the southwest monsoons and the East Asian monsoon. ${ }^{37,38}$ reveals that strong Western Pacific Subtropical High and North American Subtropical High deepen the Indian-Burma Trough. Therefore, western airflow from the Indian Ocean, southern airflow from across the equator, and eastern airflow from the southern region of the Western Pacific Subtropical High join to form southeast and southwest flows respectively. The two airflows converge to supply a warm, moist airflow to the arid northwest zone giving rise to extra precipitation, or on the contrary, to a smaller amount of precipitation. It can be seen, then, that change in the strength of these atmospheric pressure systems and their relationship regulates the rate of water vapour transfer towards the arid Northwestern region and the spatio-temporal spread of precipitation over the region. This is used quantitatively estimate the amount of contributed by each water vapour path to the arid region. This is important for thoroughly analysing the varying law of precipitation, the incidence and extent of extreme hydrological actions.

\section{b. Reinforcement construction of a non-engineering system and convert the transfer to flood management from flood control}

One main component of the flood control system that requires reinforcement is the non-engineering component. Presently, the nonengineering flood control system primarily composed of the Yishusi flood control communication system, the mainstream microwave communication system, and the hydrological telemetry system installed the upstream of Zhengyangguan. The data collection, transmission, processing, forecast and dispatch system, which is located at the Yangtze River Commission and associated four provincial water resources bureaus. This entire setup has been linked to the National General Headquarters for Flood Control. The Drought Relief Headquarters, Office of State Flood Control, the Huai River Flood Control and Drought Relief Headquarters and other relevant government offices different levels make up the nationwide flood control and drought relief command organization system. Subsequently, there is continually support the information system for water conservancy, enhance the accuracy and precision of flood scheduling and forecasting, fast track water data gathering and transmission by means of the engineering countermeasures and expand the flood risk prediction, and the effectiveness of the present project. Disaster mitigation and flood control continues to pose enormous challenge to sustainable growth of the 21 st century China. To achieve the harmonious cohabitation of nature and people, there is need to particularly fine-tune the flood control and disaster mitigation policy. All efforts towards disaster alleviation and flood control should follow the natural rules, upgrade from flood control to flood management, building of a comprehensive flood control and disaster mitigation system geared towards fostering peace between nature and humans, and to bring together of engineering and structural procedures. Aside flood prevention schemes, people need to change their behaviour through the efficient natural resources usage and reducing environmental pollution. More so, the need for people to respect flood right of ways cannot be over emphasized as well as upgrading to flood management rather than the flood control currently obtainable. The Huai River is exceedingly multifaceted. The prevalence of high occurrences of flood disasters is attributed to the special climatic features, conditions of geography, social conditions and the long-term impact of being captured by Yellow River. The instability of river-lake interconnection and socioeconomic progress persistently throws up fresh concerns and review of existing requirements. The appreciation of the River takes time and slowly enlightening practise. In the future, planning of the River should be able to take in innovations of the science and technology, deployment of fresh technologies and new approaches, regularly upgrade the perception of the central principles. In this regard, focus is to be given to the research and appreciation of the flood-waterlog and river-lake relationships. It is highly important to bind measures with socioeconomic progress, and meet the terms of the basic law of the river itself. ${ }^{39}$

\section{Land-use changes}

${ }^{40}$ revealed that the prevailing land-use kinds of the Xixian watershed were forestland and farmlands as presented in Table 2 . These contributed around $97.5 \%$ and $98.34 \%$ of the whole zone between the periods of $1980-1995$ correspondingly. During the period of review, two leading farmland types exist: paddy field and dry land until a major change to land-use patterns for years (1980 1995), which is mixture of the two farmland types. Put side-by-side with 1980 , paddy field enlarged by $1062.07 \mathrm{~km}^{2}$ (that is, $10.33 \%$ ), and dry land shrank by $1223.32 \mathrm{~km}^{2}$ (that is, $11.89 \%$ ) of the whole zone. Similarly, forestland improved by $245.27 \mathrm{~km}^{2}$ which (that is, $2.38 \%$ ) of the whole land mass. However, many modifications to land-use are inconsequential as depicted in Figure 1. The land-cover mass and changes in Xixian watershed for the 15 years (1980-1995) in terms of land-use practice are presented in Table 2. Soil and Water Assessment Tool (SWAT) is a basin-scale, physically based, continuous-time, spatially scattered scheme that functions on a daily time step with the capability to forecast the management effect on water, agricultural chemical yields, and sediment in watersheds. SWAT is capable of modelling the physical processes related to nutrient cycling, water flow, sediment transport, growth of crop, etc. To achieve this, a watershed is allocated into numerous subwatersheds, which are further subdivided into hydrologic response units (HRUs) made up of homogeneous land-use, soil characteristics, and management. The HRUs depict portions of the subwatershed zone, but unidentified spatially within a SWAT model. Otherwise, a watershed can be segmented into only subwatersheds characterized by dominant landuse, type of soil, and management.

Figure I Land cover and soil maps of Xixian Basin upper of Huia River Basin. 40

The SWAT scheme has been deployed on a number of watersheds' varieties and sizes. ${ }^{21-28}$ assess the effects of implementing of superlative management practices on pesticide fluxes arriving on surface water by means of SWAT. Again, ${ }^{29}$ appraised the influences of land-cover conversion on total water yields, groundwater flow, and fast flow in the Motueka River catchment using SWAT scheme. ${ }^{30}$ estimated 
the SWAT for hydrological modelling in the Xixian watershed and compared results with the XAJ model. Whereas, ${ }^{31}$ applied the SWAT in a Tile-Drained lowland area to determine the influence of tile drainage systems on composition of stream flow.

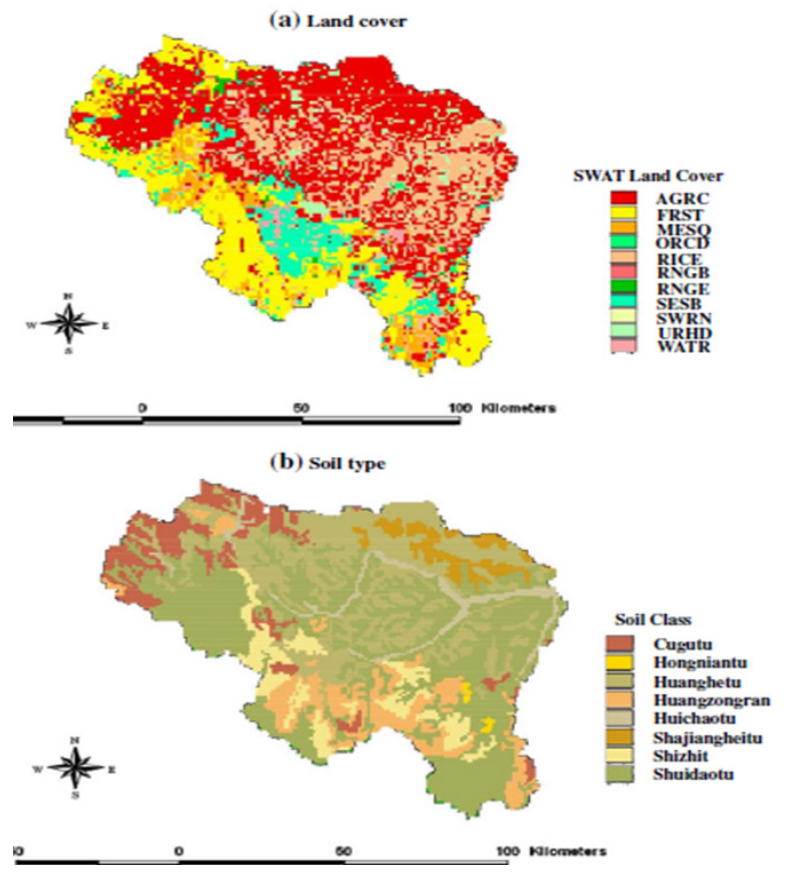

Figure I Land cover and soil maps of Xixian Basin upper of Huia River Basin. 40

Table 2 Land-cover area and changes in Xixian watershed (1980-1995)

\begin{tabular}{|c|c|c|c|c|c|c|}
\hline \multirow{2}{*}{$\begin{array}{l}\text { Land- } \\
\text { use }\end{array}$} & \multicolumn{2}{|l|}{1980} & \multicolumn{2}{|l|}{1995} & \multicolumn{2}{|c|}{$1995-1980$} \\
\hline & $\begin{array}{l}\text { Area } \\
\left(\mathrm{Km}^{2}\right)\end{array}$ & (\%) & $\begin{array}{l}\text { Area } \\
\left(\mathrm{Km}^{2}\right)\end{array}$ & (\%) & $\begin{array}{l}\text { Area } \\
\left(\mathrm{Km}^{2}\right)\end{array}$ & (\%) \\
\hline AGRC & 4340.65 & 42.20 & 3117.33 & 30.31 & -1223.32 & -11.89 \\
\hline RICE & 1736.56 & 16.88 & 2798.63 & 27.21 & 1062.07 & 10.33 \\
\hline FRST & 3953.82 & 38.44 & 4199.09 & 40.82 & 245.27 & 2.38 \\
\hline RNGB & 56.02 & 0.54 & 7.57 & 0.007 & -48.45 & -0.47 \\
\hline URHD & 144.59 & 1.41 & 121.88 & 1.18 & -22.71 & -0.23 \\
\hline WATR & 54.5 & 0.53 & 41.64 & 0.40 & -12.86 & -0.13 \\
\hline
\end{tabular}

\section{Modelling of causal factors effects on water resources}

Sodium Adsorption Ratio (SAR) is used to estimate and assess the suitability of water provided by River Basins considered for the purpose of supporting irrigation farming. SAR combined EC to determine the hazard in respect to magnesium and calcium concentrations as given by Equation 1:2

$$
S A R=\frac{m_{\mathrm{Na}^{+}}}{\sqrt{\left(m_{\mathrm{Ca}^{2+}}+m_{\mathrm{Mg}^{2+}}\right)}}
$$

Where,

$m_{i}$ depicts the ion concentration (in $\mathrm{mmol} / \mathrm{L}$ )

The amount of concentration in soluble salts in irrigation water (EC) can be classified as salinity zone:

Low, $250 \mu \mathrm{S} / \mathrm{cm}$;
Medium, $250-750 \mu \mathrm{S} / \mathrm{cm}$;

High, $750-2,250 \mu \mathrm{S} / \mathrm{cm}$;

Very high, $2,250-5,000 \mu \mathrm{S} / \mathrm{cm}$.

In irrigation water quality, the percentage of sodium is estimated by Equation 2 (Wilcox, 1995):

$$
\% \mathrm{Na}^{+}=\frac{\mathrm{Na}^{+}}{\mathrm{Ca}^{2+}+\mathrm{Mg}^{2+}+\mathrm{K}^{+} \mathrm{Na}^{+}}
$$

Units are $\mathrm{meq} / \mathrm{L}$.

Mann-Kendall rank test is a non-parametric distribution-free method suitable for detecting changes trends runoff series with least assumption for data series. ${ }^{40}$ It can be estimated by Equation 3:

$$
k=\sum_{i=1}^{n-1} \sum_{j=i+1}^{n} \operatorname{sgn}\left(x_{i}-x_{j}\right)
$$

where,

$x_{i}$ and $x_{y}$ are the sequential data values of annual runoff, and

$n$ is the length of the data set.

$$
\operatorname{sgn}\left(x_{i}-x_{j}\right)=\left\{\begin{array}{l}
0 \text { if } x_{i}-x_{j}>0 \\
1 \text { if } x_{i}-x_{j}>0
\end{array}\right.
$$

$\mathrm{U}$ is the Mann-Kendall rank test index (M-K value). Under the NULL hypothesis of no trend, the value of $n$ increases which can be represented comparable to standard normal distribution as given by Equation 5:

$$
\begin{gathered}
U=\frac{\tau}{[\operatorname{var}(\tau)]^{1 / 2}} \\
\tau=\frac{4 k}{n(n-1)}-1 \\
\operatorname{var}(\tau)=\frac{2(2 n+5)}{9 n(n-1)}
\end{gathered}
$$

When the calculated value of M-K is positive or negative; then the trend is an upward or downward correspondingly. The null hypothesis is rejected at the significance level of $\propto$ if $|U| \geq U_{\propto / 2}$, where $U_{\propto / 2}$ is the critical value of the standard normal distribution with a prospect surpassing $\propto / 2$. If $|U|<U_{\propto / 2}$, the null hypothesis is accepted representing insignificant trend. The value of $U_{\propto / 2}=1.96$ is obtained for the significant level $\propto=5 \%$.

The Variable Infiltration Capacity (VIC) model is used to measure the prospective effect of climate condition variations on water resources of the study area. ${ }^{41-43}$ The VIC model breaks down a study area into several compartments, and the soil column of each component into three layers. In most situations, the topmost two layers can be combined into one layer in order to represent the dynamic response of soil to rainfall happenings. The seasonal soil moisture behaviour is characterized by the soil lower layer. The base flow and surface flow are used to calculate the total runoffs. Surface flow consist saturation excess flow and infiltration excess flow created in the two top layers. 
The soil storage capacity distribution curve and infiltration capacity curve were used to illustrate soil properties heterogeneity. The B exponents' power functions are shown as double curves while, ARNO technique depicts lowest layer where base flow happens. ${ }^{44}$ Again, the soil moisture vertical measure is achieved with the Richard's onedimensional equation. ${ }^{45}$ To estimate effect of climate on the River Basin in terms of a physical quantity, the amount of soil wetness or dryness available is used. In the long run, soil moisture anomaly may illustrate random precipitation on the land surface, which determines growth of crops and the progress of drought events. ${ }^{46}$ In effect, soil moisture is important for agricultural drought and drought monitoring expressed by Equation $8:{ }^{47}$

$$
S M A P I=\frac{z-\bar{z}}{\bar{z}} \times 100 \%
$$

Where,

$z$ is the soil moisture content $(\mathrm{mm})$ daily simulated,

$\bar{z}$ is the multiyear average of soil moisture content (mm).

The classification of drought levels with SMAPI makes use of frequency distribution. The threshold of $-5 \%$ and lower indicates a severe drought situation around the study area. ${ }^{37}$ investigate the relationship between metrological factors and daily normalized difference vegetation index (NDVI) given by Equation 9:48-57

$$
r_{a b}=\frac{\sum_{i=1}^{n}\left(a_{i}-\bar{a}\right)\left(b_{i}-\bar{b}\right)}{\sqrt{\sum_{i=1}^{n}\left(a_{i}-\bar{a}\right)^{2} \sum_{i=1}^{n}\left(b_{i}-\bar{b}\right)^{2}}}
$$

Where,

$$
r_{a b} \text { is the correlation coefficient between } a \text { and } b \text {, }
$$

$a$ is the meteorological factors

$b$ is NDVI values if distinct grades of winter crop growth.

The significance level $(P<0.05)$ is used for hypothesis testing.

\section{Conclusion}

The problem of water cycle and distribution in areas bounded by Huia River Basin are common features in local and regional scales. In this arid northwest region, water resources are a key factor restricting socio-economic development and affecting ecological security, and plays a significant function in attaining sustainable socio-economic development in the imminently. Certain factors attributed in the area are land use, land cover and climate change. One significant developmental component of Huai River is the agriculture in upper reach known as Xixian Watershed, which is undergoing a serious change in style of cultivation style resulting in major land use modifications in nearly 30 years. There are unprecedented increases in the annual temperature trend in Huia River Basin regions/ catchment, while annual rainfall is relative stable over the period. Several research concerning quality decision making and policy breakdown of land management under climate change have separate and quantify the effect of each factor in relation to availability of portable water. Consequent upon impact of global temperature rises, the arid northwest region relies on mountain precipitation and glacial melt water as the basic source of water resource system, which is enormously fragile due to unabated progression in hydrological activities. There is higher insecurity concerning water resources, the customary rules guiding the water cycle changes and demand in ecowater. The increases in socio-economic development's water demand is largely attributed to increase the population, which continues to impact on the water resource availability and deepening scarcity. Furthermore, Northwest China's Huia River Basin is the cause of a number of chief international rivers and uncertainty of water resources occasioned by climate change continues to raise tensions among Central Asian nations. The Soil and Water Assessment Tool (SWAT) has deployed prominently for modelling the physical distribution of hydrology of HRB to ascertain the influence of land use and climate changes independently. The watershed method has largely been used for this study the effects of climatic conditions and human activities on water resources; though, it is limited by the constant modification to land use patterns usually smaller in large catchments than in small watersheds.

\section{Acknowledgments}

The authors wish to sincerely thank China Scholarship Council, China Three Gorges University and International Journal of Hydrology. The authors additionally acknowledge the editors and anonymous reviewers of this Journal whose remarks on a prior version incredibly enhanced the quality of the paper.

\section{Conflict of interest}

None.

\section{References}

1. Ma Z. Consultant to the World Bank: Evaluation of the Implementation of Water Pollution Control Plans in China: The case of Huai River Basin. 2006

2. Yang L, Song X, Zhang Y, et al. A Hydrochemical Framework and Water Quality Assessment of River Water in the Upper Reaches of the Huai River Basin, China. Environmental and Earth Sciences. 2012;67(7):2141-2153.

3. Zhang L, Song X, Xia J, et al. Major element chemistry of the Huai River Basin, China. Application of Geochemistry. 2011;26(3):293-300

4. Goudie A. The Human Impact on the Natural Environment. Oxford: Blackwell; 2006.

5. Huaihe River Commission (HRC). Huaihe River Year Book 2014. Bengbu: Huaihe River Press; 2014

6. Huang H, Yu Y, Jing L, et al. Semivolatile organic pollutants in water, suspended solids, and surface sediments of the Huaihe River, Jiangsu section, People's Republic of China. Bulletin on Environmental Contamination and Toxicology. 2004;73(2):339-346.

7. Wang BY, Zhang Z, Hu H, et al. Aquatic Ecological Risk Assessment of OCPs in Huaihe River, Jiangsu Section. China Journal of Geochemistry. 2006;25:157.

8. Hu W, Wang G, Deng W, et al. The Influence of Dams on Ecohydrological Conditions in the Huaihe River Basin, China. Ecological Engineering. 2008;33(3-4):233-241.

9. Zhang Y, Tang C, Song X, et al. Behavior and Fate of Alkylphenols in Surface water of the Jialu River, Henan Province, China. Chemosphere. 2009;77(4):559-565. 
10. Ma M, Wang C, Wang Z. Assessing Toxicities of Hydrophobic Organic Pollutants in Huaihe River by using Two Types of Sampling. Journal of Environmental Science, Health and Tox Hazard Sustainable Environmental Engineering. 2005;40(2):331-342.

11. Wang BY, Yu YJ, Huang J, et al. Health Risk Assessment of organic pollutants in Jiangsu reach of the Huaihe River, China. Water Sciences and Technology. 2009;59(5):907-916.

12. Vorosmarty CJ, Green P, Salisbury J, et al. Global Water Resources:Vulnerability from Climate Change and Population Growth. Sciences. 2000;289:284-288.

13. Li Z, Liu WZ, Zhang XC, et al. Impacts of Land Use Change and Climate Variability on Hydrology in an Agricultural Catchment on the Loess Plateau of China. Journal of Hydrology. 2009;377(12):35-42.

14. Ma X, Xu JC, Luo Y, et al. Response of Hydrological Processes to Land-cover and Climate Changes in Kejie Watershed, South-west China. Hydrological Process. 2009;23(8):1179-1191.

15. Yang T, Xu CY, Chen X, et al. Assessing the Impact of Human Activities on Hydrological and Sediment Changes (1953-2000) in Nin Major Catchments of the Loess Plateau, China. River Resources and Application. 2010;26:322-340.

16. Brath A, Montanari A, Moretti G. Assessing the Effect on Flood Frequency of Land Use Change via Hydrological Simulation (with Uncertainty). Journal of Hydrology. 2006;324(1-4):141-153.

17. Costa MH, Botta A, Cardille JA. Effects of Large-scale Changes in Land Cover on the Discharge of the Tocantins River, Southeastern Amazonia. Journal of Hydrology. 2003;283:206-217.

18. Prowse TD. Climate Change, Flow Regulation and Land-use Effects on the Hydrology of the Peace-Athabasca-Slave System: Findings from the Northern Rivers Ecosystem Initiative. Environmental Monitoring and Assessment. 2006;113(1-3):167-197.

19. Schnorbus M, Alila Y. Forest Harvesting Impacts on the Peak Flow Regime in the Columbia Mountains of Southeastern British Columbia: An Investigation usinglong-term Numerical Modeling. Water Resources Restoration. 2004;40(5):W05205.

20. DeFries R, Eshleman KN. Land-use Change and Hydrologic Processes: A Major Focus for the Future. Hydrological Process. 2004;18(11):2183-2186.

21. Arnold JG, Allen PM. Estimating Hydrological Budgets for Hhree Illinois Watersheds. Journal of Hydrology. 1996;176(1-4):55-77.

22. Arnold JG, Srinivasan R, Muttiah RS, et al. Large Area Hydrologic Modeling and Assessment: Part 1 Model Development. Journal of Advanced Modelling of Water Resources Associated. 1998;34(1):1-17.

23. Chu TW, Shirmohammadi A. Evaluation of the SWAT Model's Hydrology Component in the Piedmont Physiographic Region of Maryland. Transaction of ASAE. 2004;47(4):1057-1073.

24. Wu KS, Johnston CA. Hydrological Response to Climatic Variability in a Great Lakes Watershed: A Case Study with SWAT Model. Journal of Hydrology. 2007;337(1-2):263-279.

25. Zhang X, Srinivasan R, Van Liew M. Multi-site Calibration of the SWAT Model for Hydrologic Modeling. Transactions of ASABE. 2008;51(6):2039-2049.

26. Debele B, Srinivasan R, Gosain AK. Comparison of Process-based and Temperature-index Snowmelt Modeling in SWAT. Water Resource Management. 2010;24(6):1065-1088.

27. Meiyan Y, Xi C, Lanhai L, et al. Streamflow Simulation by SWAT using Different Precipitation Sources in Large arid Basins with Scarce Raingauges. Water Resource Management. 2011;25:2669-2681.

28. Holvoet K, Gevaert V, Griensver AV, et al. Modelling the Effectiveness of Agricultural Measures to Reduce the Amount of Pesticides Entering Surface Waters. Water Resource Management. 2007;21(12):2027-2035

29. Cao W, Bowden WB, Davie T, et al. Modelling Impacts of Land Cover Change on Critical Water Resources in the Motueka River Catchment. NZ Water Resource Management. 2009;23(1):137-151.

30. Peng S, Chao C, Ragahavan S, et al. Evaluating the SWAT model for Hydrological Modeling in the XixianWatershed and a Comparison with the XAJ Model. Water Resource Management. 2011;25(10):2595-2612.

31. Stefan K, Andreas B, Bernd L. Application of the SWAT Model for a Tile-Drained Lowland Catchment in North-Eastern Germany on Subbasin Scale. Water Resource Management. 2012;27(3):791-805.

32. Wang SJ, Zhang MJ, Li ZQ. Glacier area variation and climate change in the Chinese Tianshan Mountains since 1960. Journal of Geographical Sciences. 2011;21(2):263-273.

33. Li Z, Chen YN, Shen YJ. Analysis of Changing Pan Evapouration in the Arid Region of Northwest China. Water Resources Research. 2013;49:2205-2212.

34. Kuznets S. Development of the Modern Economy. Beijing: Beijing Institute of Economy Press; 1986

35. Nian YY, Li X, Zhou J. Impact of Land Use Change on Water Resource Allocation in the Middle Reaches of the Heihe River Basin in Northwestern China. Journal of Arid Land. 2014;6(3):273-286.

36. De Bruyn SM, Vanden Bergh JC, Opschoor JB. Economic Growth and Emissions: Reconsidering the Empirical Basis of Environmental Kuznets Curves. Ecological Economics. 1998;25(2):161-175.

37. Huang Q, Wang L, Chen Z, et al. Effects of Meteorological Factors on Different Grades of Winter Wheat Growth in the Huang-Huai-Hai Plain, China. Journal of Integrative Agriculture. 2016;15(11):2647-2657

38. Chen Y, Li B, Li Z, et al. Water Resource Formation and Conversion and Water Security in Arid Region of Northwest China. Journal of Geographical Sciences. 2016;26(7):939-952.

39. Zhao CS, Liu C, Xia J, et al. Recognition of Key Regions for Restoration of Phytoplankton Communities in the Huai River Basin, China. Journal of Hydrology. 2012;420-421(4):292-300.

40. Shi Y. On the Pollution Treatment of the Huaihe River Valley. Journal of Environment and Heritage. 1999;1:1-4.

41. Liang X, Lettenmaier DP, Wood EF. A Simple Hydrological Model for Land Surface and Energy Fluxes for General Circulation Models. Journal of Geophysics. 1994;99(D7):14415-14428.

42. Lohmann D, Raschke E, Nijssen B. Regional Scale Hydrology-I: Formation of the VIC-2L Model Coupled to a Routing Model. Hydrological Science Journal. 1998;43(1):131-141.

43. Liang X, Xie Z. A New Surface Runoff Parameterization with Subgrid-Scale Soil Heterogeneity for Land Surface Model. Advances in Water Resources. 2001;24(9-10):1173-1193.

44. Mao Y, Wu Z, He H, et al. Spatio-Temporal Analysis of Drought in a Typical Plain Region Based on Soil Moisture Anomaly Percentage Index. Science of the Total Environment. 2016;576:752-765.

45. Zhang YJ, Liu Z, Zhang H, et al. The Impact of Economic Growth, Industrial Structure and Urbanization on Carbon Emission Intensity in China. National Hazards. 2014;73(2):579-595. 
46. Wang GO, Zhang JY, Jin JL, et al. Assessing Water Resources in China using RECIS and VIC Model. Hydrologu and Earth Science. 2012;16(1):231-240.

47. Wu ZY, Lu GH, Lin CA. Restructuring and Analyzing China's FiftyNine Year (1951-2009). Hydrology and Earth Systems Sciences. 2011;15(9):2881-2894.

48. Abu ZMA. Water and Sustainable Sevelopment: The Vision for World Water, Life and the Environment. Water Policy. 1998;1(1):9-19.

49. Biswas AK. Water for Sustainable Development in the $21 \mathrm{st}$ Century. International Journal of Water Resources Development. 1991;7(4):219-224.

50. Cai X. Implementation of Holistic Water Resources-Economic Optimization Models for River Basin Management-Reflective Experiences. Environmental Modelling Software. 2008;23(1):2-18.

51. Chen YN, Li Z, Fan YT. Progress and Prospects of Climate Change Impacts on Hydrology in the Arid Region of Northwest China. Environmental Research. 2015;139:11-19.
52. Global Environmental Institute (GEI). Regulation on national general survey of pollution sources. China: GEI; 2008.

53. IPCC. Climate change 2007: Synthesis report. Contribution of Working Groups I, II and III to the Fourth. Cambridge: Cambridge University Press; 2007.

54. Liu B, Speed R. Water Resources Management in the People's Republic of China. International Journal of Water Resources Distribution. 2009;25(2):193-208.

55. Mays LW. Water Resources Sustainability. New York: McGrawHill; 2007.

56. Mays LW. Groundwater Resources Sustainability: Past, Present, and Future. Water Resources Management. 2013;27(13):4409-4424.

57. Ni X, Wu Y, Wu J, et al. Scenario Analysis for Sustainable Development of Chongming Island: Water Resources Sustainability. Science for Total Environment. 2012;439:129-135. 